Jurnal Administrasi Negara

ISSN : 2598-4039 (Online)

ISSN : 2302-2231 (Print)
Mas Wigrantoro Roes Setyadi, dkk

Institut Pemerintahan Dalam Negeri, Jatinangor Jawa Barat

\title{
PENGARUH KEPEMIMPINAN BIROKRASI DAN IMPLEMENTASI ELECTRONIC GOVERNMENT TERHADAP KUALITAS PELAYANAN PUBLIK KEPENDUDUKAN DAN PENCATATAN SIPIL DI KOTA CILEGON
}

\author{
Mas Wigrantoro Roes Setyadi ${ }^{1}$, Ermaya Suradinata ${ }^{2}$, \\ Sampara Lukman ${ }^{3}$, Ika Sartika ${ }^{4}$ \\ Institut Pemerintahan Dalam Negeri, Jatinangor Jawa Barat \\ *Coressponding Author. Email : maswig@gmail.com
}

\begin{abstract}
One of the supporting factors for the success of the bureaucracy in carrying out its functions as executor of public services is the existence of quality of bureaucratic leadership. As a means of improving the quality of public services organized by the bureaucracy, some developed countries have implemented Electronic Government. This study aims to explore new concepts for the development of bureaucratic leadership theory and electronic government implementation of the quality of public services. The design of the study used a quantitative approach to test the truth of the theory against empirical reality from the influence of bureaucratic leadership variables (X1) and the implementation of Electronic Government (X2) on the quality of public services $(Y)$. The results of this study, Bureaucratic Leadership proved to have a positive effect on Public Service Quality, amounting to 39.6\%. The implementation of Electronic Government proved to have a positive effect on the Quality of Public Services, amounting to 33.9\%. Bureaucratic leadership and Electronic Government Implementation together have a positive effect on the Quality of The Population and Civil Registration services in the Cilegon Municipality Population and Civil Registration Agency, at 28.6\%. In order to preserve this positive influence, Cilegon Municipality Bureaucracy leaders are advised to continue to improve: Employee Motivation, Employee Quality, Effectiveness of Electronic Government-based Service Socialization, Electronic Government-based Organizational Culture, and e-Leadership.
\end{abstract}

Keywords: Bureaucratic Leadership, Electronic Government, Public Services

\begin{abstract}
Abstrak
Salah satu faktor penunjang keberhasilan birokrasi dalam menjalankan fungsinya sebagai pelaksana pelayanan publik adalah adanya kepemimpinan birokrasi yang berkualitas. Sebagai sarana dalam upaya meningkatkan kualitas pelayanan publik yang diselenggarakan oleh birokrasi, beberapa negara maju mengimplementasikan Electronic Government. Penelitian ini bertujuan untuk menggali konsep baru bagi pengembangan teori Kepemimpinan Birokrasi dan Implementasi Electronic Government terhadap Kualitas Pelayanan Publik. Desain penelitian yang digunakan dengan pendekatan kuantitatif untuk menguji kebenaran teori terhadap kenyataan empirik dari pengaruh variabel kepemimpinan birokrasi $\left(X_{1}\right)$ dan implementasi Electronic Government $\left(X_{2}\right)$ terhadap kualitas pelayanan publik (Y). Hasil penelitian ini, Kepemimpinan Birokrasi terbukti berpengaruh positif terhadap Kualitas Pelayanan Publik, sebesar 39.6\%. Implementasi Electronic Government terbukti berpengaruh positif terhadap Kualitas Pelayanan Publik, sebesar 33.9\%. Kepemimpinan Birokrasi dan Implementasi Electronic Government secara bersama berpengaruh positif pada kualitas Pelayanan Publik Kependudukan dan Pencatatan Sipil di Dinas Kependudukan dan Pencatatan Sipil Kota Cilegon sebesar 28,6\%. Guna menjaga kelestarian pengaruh positif ini, pimpinan Birokrasi Kota Cilegon disarankan untuk terus meningkatkan: Motivasi Pegawai, Kualitas Pegawai, Efektifitas Sosialisasi Pelayanan berbasis electronic Government, Budaya Organisasi berbasis Electronic Government, dan e-Leadership.
\end{abstract}

Kata Kunci: Kepemimpinan Birokrasi ,E-Government, Pelayanan Publik. 
Jurnal Administrasi Negara

ISSN : 2598-4039 (Online)

ISSN : 2302-2231 (Print)
Mas Wigrantoro Roes Setyadi, dkk

Institut Pemerintahan Dalam Negeri, Jatinangor Jawa Barat

\section{PENDAHULUAN}

Pemerintahan adalah sebuah sistem multiproses yang bertujuan memenuhi dan melindungi kebutuhan dan tuntutan pihak yang diperintah akan jasa publik dan layanan civil. Ndraha (2015:7) memaknai pemerintah sebagai organ yang berwenang memproses pelayanan publik dan berkewajiban memproses pelayanan civil bagi setiap orang melalui hubungan pemerintahan, sehingga setiap anggota masyarakat yang bersangkutan menerimanya pada saat diperlukan, sesuai dengan tuntutan (harapan) yang diperintah. Untuk menjalankan fungsinya sebagai penyedia layanan publik, pemerintah memiliki birokrasi, instrumen administrasi untuk melaksanakan kebijakan-kebijakan (Riggs et all, 2009:86). Birokrasi memiliki peran sentral dalam kehidupan masyarakat modern saat ini (Peters, 2001:15). Sebagai alat atau mekanisme dari keputusan politik, birokrasi nyata mempunyai posisi yang strategis. Di satu sisi menjadi penerjemah dan sekaligus implementor kebijakan publik, di sisi lain sebagai pelayan publik yang harus responsif terhadap kebutuhan maupun aspirasi masyarakat. Birokrasi berada dalam posisi sebagai kepanjangan tangan penguasa (negara) sekaligus juga "penyambung lidah" bagi tuntutan dan harapan publik akan sistem pemerintahan yang baik dan bersih.

Salah satu faktor penunjang keberhasilan birokrasi dalam menjalankan fungsinya sebagai pelaksana pelayanan publik adalah adanya kepemimpinan birokrasi yang berkualitas. Suradinata (2013:4-6) menekankan pentingnya etika kepemimpinan bagi pemimpin pemerintahan. Kepemimpinan pemerintahan adalah kemampuan seseorang sebagai pemimpin selain berkemampuan pemerintahan juga memiliki kemampuan mengambil putusan secara tepat, cepat, terukur, serta memimpin taat pemerintahan yang baik, yaitu mengelola sumber daya menjadi sumber daya yang berkualitas tinggi berdasarkan etika pemerintahan.

Sebagai sarana dalam upaya meningkatkan kualitas pelayanan publik yang diselenggarakan oleh birokrasi, beberapa negara maju mengimplementasikan Electronic Government (Mohammad, Almarabeh, dan Abu Ali, 2009:190). Dalam Electronic Government yang terjadi tidak hanya otomatisasi layanan publik, namun lebih dari itu, terjadi efisiensi dan peningkatan produktivitas, serta peningkatan citra pemerintah di hadapan masyarakat yang dilayaninya. Implementasi Electronic Government menciptakan transparansi pelayanan publik, dan dapat mendorong transisi dari masyarakat sebagai "penduduk" menjadi sebagai pelaku atau "subyek" (Budd \& Harris, 2009:44). Adanya pengakuan sebagai "penduduk" menjadikan warganegara dapat lebih mudah mengakses informasi. Hal ini terwujud dalam hubungan antara pemerintah dengan individu dalam kerangka pelayanan publik menggunakan Electronic Government.

Begitu pula halnya di Kota Cilegon. Jika hanya dilihat dari fakta yang tampak, terlihat ada upaya yang sangat kuat oleh kepemimpinan birokrasi di Kota Cilegon dalam mengupayakan pelayanan publik berbasiskan Electronic Government. Namun, jika dikaitkan dengan bentuk ideal Kepemimpinan Birokrasi dan implementasi Electronic Government serta dampaknya terhadap kualitas pelayanan publik di Kota Cilegon, dapat 
Jurnal Administrasi Negara

ISSN : 2598-4039 (Online)

ISSN : 2302-2231 (Print)
Mas Wigrantoro Roes Setyadi, dkk

Institut Pemerintahan Dalam Negeri, Jatinangor Jawa Barat dikatakan sarana pelayanan publik berbasis Electronic Government Pemerintah Daerah yang diwujudkan melalui websites www.cilegon.go.id masih berfungsi sebagai media informatif/komunikatif dan belum menjadi media interaktif, apalagi transformatif. Jika dikaitkan dengan panduan yang diterbitkankan Dinas Komunikasi dan Informatika (Kominfo), maka status dari websites Pemerintah Kota Cilegon masih pada tahapan pematangan yaitu masih dalam kategori penyediaan informasi interaktif.

Termasuk Pelayanan Kependudukan dan Pencatatan Sipil berbasis Electronic Government di Kota Cilegon dinilai masih bermasalah oleh masyakarat. Meskipun Disdukcapil Kota Cilegon menyatakan kinerjanya tergolong tinggi, namun sebagian warga masyarakat masih ada yang mengeluhkan kualitas pelayanannya, padahal pelayanan Disdukcapil berkaitan langsung dengan hak dasar warga, khususnya yang terkait identitas. Ditambah lagi, data kependudukan dan pencatatan sipil sangat strategis perannya dalam perencanaan pembangunan, pemilihan umum, dan pilkada.

Dari penelusuran di Kota Cilegon yang sudah dilakukan ditemukan beberapa masalah. Pertama, berdasarkan dugaan awal, permasalahan yang terdapat dalam pelayanan Kependudukan dan Pencatatan Sipil merupakan dampak dari kepemimpinan birokrasi yang ada. Kedua, di kalangan masyarakat, Implementasi Electronic Government sebagai kanal pelayanan publik pemerintah kota Cilegon tidak begitu dirasakan keberadaannya oleh masyarakatnya. Aplikasi layanan online untuk masyarakat di website Pemerintah kota Cilegon, www.cilegon.go.id tidak banyak tersedia, atau tersedia namun belum dimanfaatkan oleh masyarakat secara optimal. Masyarakat yang mengakses website kota Cilegon sebagai portal layanan pertama hanya sebanyak 1.460 per tanggal 14 Mei 2017. Ketiga, Pusat Pelayanan Informasi Daerah (PPID) sebagai pengelola layanan informasi publik pemerintah kepada masyarakat tidak terepresentasi karena tidak tersedia kanal PPID di website Pemerintah Kota Cilegon. Keempat, pengelolaan Sumber Daya Manusia (SDM) dalam Implementasi Electronic Government di Cilegon masih terkendala. Dinas Komunikasi, Informatika, Sandi dan Statistik memiliki SDM yang sebagian besar tidak sesuai dengan bidang dan keahlian yang dibutuhkan untuk mengelola Electronic Government. Kelima, kondisi birokrasi di Kota Cilegon saat ini mengalami pengelompokan. Menurut www.kabar- banten.com (10 Juli 2017), ada kecenderungan pengelompokan atau faksi di antara para birokrat di Lingkungan Pemkot Cilegon. Kelompok tersebut terbagi menjadi tiga, yakni faksi Aparatur Sipil Negara (ASN) alumni STPDN (Sekolah Tinggi Pemerintahan Dalam Negeri), faksi ASN asal Jawa Barat (disebut Kelompok Kujang), serta faksi ASN yang berasal dari masyarakat asli Cilegon (Kelompok Putra Daerah). Pengelompokan tersebut diketahui oleh Walikota Cilegon. Menurut Ariyadi, menciptakan faksi di kalangan birokrat, adalah perbuatan tidak menguntungkan. Faksi-faksi ini dapat berpengaruh pada proses pelayanan publik secara keseluruhan. Keenam, berdasarkan laporan Ombudsman Republik Indonesia tahun 2015, Kota Cilegon masuk kategori Zona merah yang menandakan tingkat kepatuhan dalam pelaksanaan UU 25 Tahun 2009 tentang 
Jurnal Administrasi Negara

ISSN : 2598-4039 (Online)

ISSN : 2302-2231 (Print)
Mas Wigrantoro Roes Setyadi, dkk

Institut Pemerintahan Dalam Negeri, Jatinangor Jawa Barat
Pelayanan Publik bernilai rendah. Berdasarkan hasil kajian Ombudsman Republik Indonesia, Kota Cilegon berada pada posisi 48 dari 50 kota yang dijadikan sampel dengan nilai 18.72 . Berdasarkan fakta tersebut kota Cilegon memiliki masalah dalam kepatuhan tentang ketentuan Pelayanan Publik yang sudah ditentukan pada UU No. 25 tahun 2009.

Permasalahan dalam pelayanan publik di Kota Cilegon sebagaimana dinyatakan dalam RPJMD Tahun 20162021, mencakup hampir semua bidang layanan publik, dalam tingkatan yang bervariasi. Dari aspek ekonomi, laju pertumbuhan ekonomi cenderung melambat, di bawah angka pertumbuhan ekonomi Nasional dan Provinsi Banten. Pelambatan ekonomi ini dibarengi tingkat inflasi yang angkanya di atas tingkat inflasi nasional. Dalam aspek ketenagakerjaan terjadi paradoks, sementara Cilegon terkenal sebagai kota industri baja dan kimia, serta ada ratusan industri manufaktur lainnya, namun angka pengangguran di Kota Cilegon tergolong tinggi.

Dalam aspek kepemimpinan birokrasi, menggunakan skala kelincahan kepemimpinan (agility leadership) tingkat kemampuan kepemimpinan birokrasi dalam menjalankan organisasi mencapai visi dan misi masih berada pada level yang relatif rendah. Hal ini mencerminkan masih besarnya peluang untuk meningkatkan kualitas kepemimpinan. Dari aspek implementasi Electronic Government yang dimaksudkan sebagai sarana otomatisasi pelayanan publik, dapat dikatakan websites www.cilegon.go.id masih berfungsi sebagai media informatif saja, belum sampai pada tingkat interaktif ataupun integratif, hingga transformatif.
Lebih jauh, keberadaan Electronic Government belum dirasakan manfaatnya oleh masyarakat, penggunanya relatif kecil bila dibandingkan dengan populasi penduduk. Kondisi ini disumbang oleh kualitas dan kuantitas Sumber Daya Manusia yang mengelola implementasi Electronic Government secara umum belum memiliki kompetensi yang mencukupi. Di pihak lain ada juga permasalahan yang latent namun jarang sekali yang mengakui keberadaannya yakni kecenderungan adanya fragmentasi (pengelompokan) di dalam birokrasi Pemerintah Kota Cilegon

Kemudian, ditemukan pula, pada saat ini di Pemerintah Kota Cilegon, penyelenggaraan layanan publik khususnya yang dilakukan menggunakan Electronic Government, belum berhasil meningkatkan kualitas pelayanannya. Sedangkan di masyarakat, ditemukan cukup banyak anggota masyarakat yang belum terlayani, baik masih terdapatnya suasana atau iklim yang tidak memungkinkan potensi masyarakat memanfaatkannya, lemahnya potensi atau daya yang dimiliki masyarakat, serta terjadinya persaingan yang tidak seimbang di masyarakat.

Berbagai fenomena tersebut di atas, khususnya yang terkait dengan kualitas pelayanan publik, diduga dipengaruhi oleh kepemimpinan birokrasi di lingkungan Pemerintah Kota Cilegon dan implementasi Electronic Government oleh birokrasi Pemerintah Kota Cilegon, yang sekaligus menunjukkan komitmen perangkat daerah dalam proses pelaksanaan masih kurang efektif. Kondisi tersebut diduga terjadi karena hal-hal sebagai berikut :

1. Pimpinan Birokrasi Pemerintah Kota CIlegon masih menghadapi permasalahan dalam tugasnya sebagai 
Jurnal Administrasi Negara

ISSN : 2598-4039 (Online)

ISSN : 2302-2231 (Print)
Mas Wigrantoro Roes Setyadi, dkk

Institut Pemerintahan Dalam Negeri, Jatinangor Jawa Barat penanggung jawab penyedia pelayanan publik.

2. Implementasi Electronic Government belum mampu meningkatkan kualitas pelayanan publik kepada warga masyarakat Kota Cilegon secara umum.

3. Belum semua Pimpinan Birokrasi, khususnya di tingkat menengah dan atas, seperti Kepala Dinas atau pejabat Eselon dua, memahami secara komprehensif apa dan bagaimana Electronic Government dapat mendorong peningkatan Kualitas Pelayanan Publik.

4. Di antara bidang pelayanan publik yang masih terkendala, pelayanan Kependudukan dan Pencatatan Sipil tergolong yang sensitif dan secara kuantitatif menerima banyak keluhan dari masyarakat.

5. Pemerintah Kota Cilegon belum memilki strategi kepemimpinan birokrasi yang secara khusus dimaksudkan untuk meningkatkan kualitas pelayanan publik melalui Implementasi Electronic Government.

Penelitian ini bertujuan untuk menggali konsep atau teori baru bagi pengembangan Ilmu Pemerintahan terkait dengan Kepemimpinan Birokrasi dan Implementasi Electronic Government terhadap Kualitas Pelayanan Publik.

Adapun tujuan penelitian ini adalah untuk menganalisis:

1. Pengaruh langsung maupun tidak langsung Kepemimpinan Birokrasi terhadap Kualitas Pelayanan Publik Kependudukan dan Pencatatan Sipil di Kota Cilegon.

2. Pengaruh langsung maupun tidak langsung Implementasi Electronic Government terhadap Kualitas Pelayanan Publik Kependudukan dan Pencatatan Sipil di Kota Cilegon.
3. Pengaruh langsung maupun tidak langsung Kepemimpinan Birokrasi dan Implementasi Electronic Government secara bersama terhadap Kualitas Pelayanan Publik Kependudukan dan Pencatatan Sipil di Kota Cilegon.

\section{METODE PENELITIAN}

Desain penelitian yang digunakan adalah penelitian kuantitatif yang merupakan penyelidikan tentang fenomena sosial atau manusia yang berdasarkan pada pengujian sebuah atau beberapa teori yang terdiri dari variabelvariabel, diukur dengan angka dan dianalisis dengan prosedur statistik untuk menentukan apakah generalisasi prediktif teori tersebut benar (Creswell 1994:1). Artinya desain penelitian penyelidikan tentang fenomena kepemimpinan birokrasi dan implementasi Electronic Government terhadap kualitas pelayanan publik di Kota Cilegon Provinsi Banten yang diuji kebenaran teori terhadap kenyataan empirik dari variabel yang dimaksud untuk menggenalisir adanya hubungan dan pengaruh variabel kepemimpinan birokrasi $\left(\mathrm{X}_{1}\right)$ dan implementasi Electronic Government $\left(\mathrm{X}_{2}\right)$ terhadap kualitas pelayanan publik (Y). Alasannya adalah karena prinsip penelitian ini adalah untuk memperoleh informasi melalui pengamatan dan penalaran empirik yang dipergunakan dalam pengembangan secara sistimatis berdasarkan dalil-dalil yang berkaitan secara logis untuk menetapkan variabel kepemimpinan birokrasi $\left(\mathrm{X}_{1}\right)$ dan implementasi Electronic Government $\left(\mathrm{X}_{2}\right)$ terhadap kualitas pelayanan publik (Y).

\begin{tabular}{lrr}
\multicolumn{3}{r}{ Penelitian ini melakukan generalisasi } \\
atas fenomena & dari & pengaruh \\
kepemimpinan & birokrasi & dan
\end{tabular}


Jurnal Administrasi Negara

ISSN : 2598-4039 (Online)

ISSN : 2302-2231 (Print)
Mas Wigrantoro Roes Setyadi, dkk

Institut Pemerintahan Dalam Negeri, Jatinangor Jawa Barat implementasi Electronic Government terhadap kualitas pelayanan publik. Artinya kualitas pelayanan publik dengan tetap memperhitungkan hasil observasi dan wawancara mendalam dengan beberapa responden yang baik memahami masalah penelitian ini.

Obyek penelitian ini adalah kepemimpinan birokrasi, implementasi Electronic Government, dan (3) kualitas pelayanan publik, (4) strategi kepemimpinan birokrasi dalam implementasi Electronic Government untuk meningkatkan kualitas pelayanan publik di Kota Cilegon, dan (5) model Kepemimpinan Birokrasi Untuk Pelayanan Publik Berbasis Electronic Government.

Kepemimpinan birokrasi meliputi; menggerakkan dengan Visi-Misi, memotivasi bawahan, memiliki kompetensi, dan akuntabel. Implementasi Electronic Government mencakup; membuat pekerjaan lebih efektif, layanan berbasis online, kemudahan akses ke data dan informasi, mengurangi biaya yang terkait dengan pihak ketiga, mengurangi biaya administrasi, keakuratan data dan informasi, situs web dapat digunakan sebagai media komunikasi yang efektif dalam penyelenggaraan pemerintahan daerah yang berhubungan dengan kualitas pelayanan publik yang meliputi; perspektif kualitas pelayanan, perspektif pelayanan informasi, perspektif kualitas organisasi dalam suatu pemerintahan bermakna penyediaan kemudahan dan kemanfaatan kepada masyarakat dalam mencapai hidup yang sejahtera dan bermartabat.

Paradigma baru dalam suatu pemerintahan modern selalu berorientasi pada sikap mendahulukan kepentingan publik dengan meningkatkan kualitas pelayanan dalam rangka memberikan kepuasan masyarakat. Pemerintah bertanggung jawab memenuhi dan melindungi tuntutan kebutuhan masyarakat, untuk itu diperlukan suatu bentuk pemerintahan yang tidak lagi menampilkan diri sebagai sosok penguasa, akan tetapi pemerintah yang mesti melayani setiap kepentingan sesuai dengan aspirasi yang berkembang dalam masyarakat di masa mendatang.

Dalam pelaksanaan penelitian ini, penulis melakukan penelitian ilmiah untuk menjawab masalah penelitian yang diajukan dengan penekanan pada:

1. Memahami proses dan mekanisme tentang kepemimpinan birokrasi meliputi; menggerakkan dengan VisiMisi, memotivasi bawahan, memiliki kompetensi, dan akuntabel.

2. Kemampuan untuk menjawab atau memenuhi janji atau commitment implementasi Electronic Government mencakup; membuat pekerjaan lebih efektif, layanan berbasis online, kemudahan akses ke data dan informasi, mengurangi biaya yang terkait dengan pihak ketiga, mengurangi biaya administrasi, keakuratan data dan informasi, situs web dapat digunakan sebagai media komunikasi yang efektif dalam penyelenggaraan pemerintahan daerah yang merupakan sebuah investasi jangka panjang.

3. Mengungkap dan memahami persoalan kualitas pelayanan publik meliputi; perspektif kualitas pelayanan, perspektif pelayanan informasi, perspektif kualitas organisasi yang menjadi fokus disiplin Ilmu Pemerintahan di Indonesia yang komperehensif.

4. Mengembangkan strategi kepemimpinan birokrasi dalam implementasi Electronic Government 
Jurnal Administrasi Negara

ISSN : 2598-4039 (Online)

ISSN : 2302-2231 (Print)
Mas Wigrantoro Roes Setyadi, dkk

Institut Pemerintahan Dalam Negeri, Jatinangor Jawa Barat untuk meningkatkan kualitas pelayanan publik di Kota Cilegon.

5. Mengusulkan Model Kepemimpinan

Birokrasi Untuk Pelayanan Publik

Berbasis Electronic Government.

Berbagai tuntutan kepemimpinan birokrasi dan implementasi Electronic Government terhadap kualitas pelayanan publik sebagai tanda ketidak-puasan masyarakat sehari-hari banyak dilihat. Diakui bahwa kualitas pelayanan publik yang diberikan oleh pemerintah daerah terus mengalami pembaharuan, baik dari sisi paradigma, maupun format kualitas pelayanan publik seiring dengan meningkatnya tuntutan masyarakat dan perubahan di dalam Pemerintah Kota Cilegon Provinsi Banten. Meskipun demikian, pembaharuan dilihat dari kedua sisi tersebut belumlah memuaskan, bahkan masyarakat masih diposisikan sebagai pihak yang tidak berdaya dan termarginalisasikan dalam kerangka kualitaas pelayanan publik. Secara keseluruhan fenomena yang disebutkan di atas didasarkan pada beberapa referensi teoretik dan realitas Ilmu Pemerintahan secara faktual, sehingga yang disorot dalam penelitian ini mencerminkan pijakan secara teoretik dan pijakan secara praktis.

Sebagai obyek dalam penelitian ini adalah pemerintah daerah dan masyarakat sebagai user dari kepemimpinan birokrasi dan implementasi Electronic Government terhadap kualitas pelayanan publik di Kota Cilegon Provinsi Banten. Penelitian ini dilakukan dengan memperhatikan waktu pelaksanaan penelitian dan kemampuan dana, dan daya dukung lainnya dengan tidak mengabaikan kedalaman subtansi penelitian.

Paradigma penelitian dilakukan dengan menggunakan tiga variabel, sehingga bentuk hubungannya didasarkan pada tiga variabel saja, yaitu variabel bebas (independent variable). Dalam penelitian ini yang merupakan variabel bebas adalah kepemimpinan birokrasi $\left(\mathrm{X}_{1}\right)$ ditentukan Kepemimpinan birokrasi meliputi; menggerakkan dengan Visi-Misi, memotivasi bawahan, memiliki kompetensi, dan akuntabel dan implementasi Electronic Government $\left(\mathrm{X}_{2}\right)$ ditentukan membuat pekerjaan lebih efektif, layanan berbasis online, kemudahan akses ke data dan informasi, mengurangi biaya yang terkait dengan pihak ketiga, mengurangi biaya administrasi, keakuratan data dan informasi, Situs web dapat digunakan sebagai media komunikasi yang efektif. Sedangkan yang merupakan variabel terikat (dependent variable) kualitas pelayanan publik (Y) ditentukan meliputi; perspektif kualitas pelayanan, perspektif pelayanan informasi, perspektif kualitas organisasi. Paradigma penelitian ini digambarkan secara sederhana sebagai berikut:

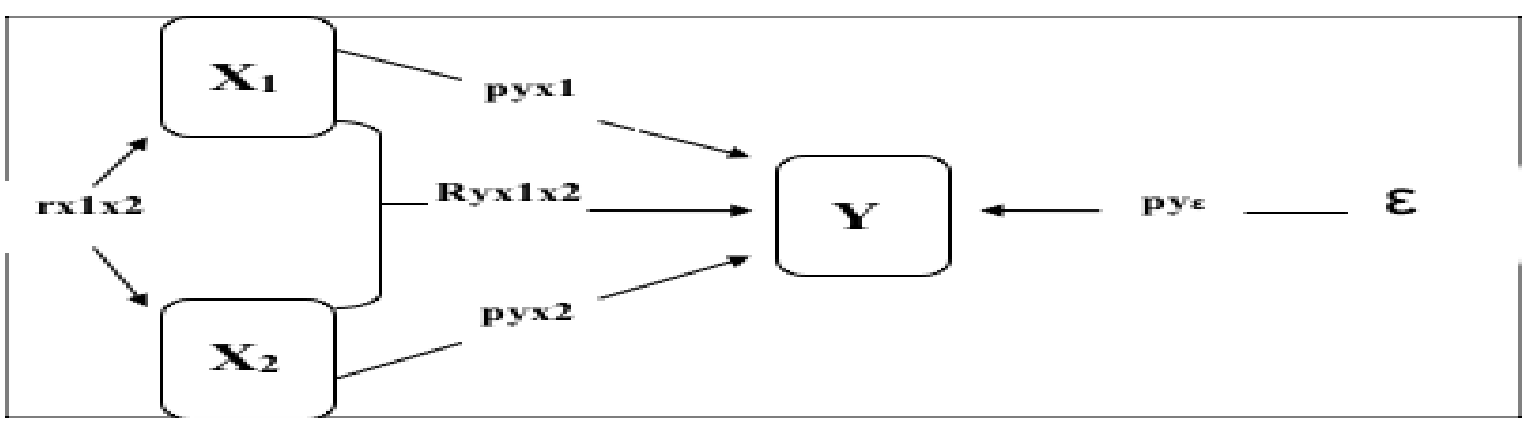

Gambar 1. Paradigma Penelitian 
Jurnal Administrasi Negara

ISSN : 2598-4039 (Online)

ISSN : 2302-2231 (Print)
Mas Wigrantoro Roes Setyadi, dkk

Institut Pemerintahan Dalam Negeri, Jatinangor Jawa Barat
Untuk kepentingan penelitian ini, operasionalisasi variabel dimaksudkan untuk memberikan masukan yang lebih jelas dalam menyusun alat ukur diperlukan, berdasarkan variabel yang terdapat pada hipotesis di atas dikemukakan variabel-variabel penelitian sebagai berikut :

1. Variabel bebas (independent variable) adalah kepemimpinan birokrasi $\left(\mathrm{X}_{1}\right)$ meliputi dimensi menggerakkan dengan Visi-Misi, memotivasi bawahan, memiliki kompetensi, serta akuntabel dan implementasi Electronic Government $\left(\mathrm{X}_{2}\right)$ meliputi dimensi membuat pekerjaan lebih efektif, layanan berbasis online, kemudahan akses ke data dan informasi, mengurangi biaya yang terkait dengan pihak ketiga, mengurangi biaya administrasi, keakuratan data dan informasi dan Situs web dapat digunakan sebagai media komunikasi yang efektif.

2. Variabel terikat (dependent variable) adalah kualitas pelayanan publik (Y) meliputi dimensi dimensi perspektif kualitas pelayanan, perspektif pelayanan informasi dan perspektif kualitas organisasi.

\section{HASIL DAN PEMBAHASAN}

Pengaruh Kepemimpinan Birokrasi Terhadap Kualitas Pelayanan Publik

Berdasarkan hasil uji hipotesis penelitian tentang pengaruh Kepemimpinan Birokrasi dan Implementasi Electronic Government terhadap Kualitas Pelayanan Dinas Kependudukan dan Pencatatan Sipil di Kota Cilegon dengan beberapa tahapan pengujian, dari hasil uji t menunjukkan bahwa hipotesis Hal diterima yang berbunyi secara parsial "Terdapat
Pengaruh yang signifikan variabel Kepemimpinan Birokrasi terhadap variabel Kualitas Pelayanan" terbukti dengan $\mathrm{t}$ hitung > t tabel yaitu 9,127> 0,098 dengan tingkat signifikansi $0.000<$ 0,05 . Sedangkan besarnya pengaruh variabel Kepemimpinan Birokrasi terhadap variabel Kualitas Pelayanan sebesar 0,396 atau 39,6\%. Dengan kata lain variabel Kepemimpinan Birokrasi memberikan pengaruh 39,6\% kepada variabel Kualitas Pelayanan dan sisanya $60,4 \%$ oleh variabel lain.

Berdasarkan hasil perhitungan dengan analisis regresi linier berganda diperoleh persamaan / model regresi dibawah ini:

$$
\begin{aligned}
& Y=a+b_{1} X_{1}+b_{2} X_{2} \\
& Y=48,247+0,396 X_{1}+0,339 X_{2}
\end{aligned}
$$

Dari nilai perolehan persamaan model regresi linier berganda diketahui bahwa Kepemimpinan Birokrasi (X1) menunjukkan nilai koefisien regresi positif, hal tersebut menunjukkan adanya arah positif atau hubungan searah dari Kepemimpinan Birokrasi (X1) dengan Kualitas Pelayanan (Y). Hal ini dapat diartikan bahwa jika semakin meningkat Kepemimpinan Birokrasi maka Kualitas Pelayanan akan semakin meningkat, begitu pula sebaliknya jika semakin menurun Kepemimpinan Birokrasi maka Kualitas Pelayanan akan semakin menurun.

\section{Pengaruh Implementasi Electronic Government Terhadap Kualitas Pelayanan Publik.}

Hipotesis $\mathrm{Ha} 2$ diterima yang berbunyi secara parsial "Terdapat pengaruh signifikan Implementasi Electronic Government terhadap Kualitas 
Jurnal Administrasi Negara

ISSN : 2598-4039 (Online)

ISSN : 2302-2231 (Print)
Mas Wigrantoro Roes Setyadi, dkk

Institut Pemerintahan Dalam Negeri, Jatinangor Jawa Barat
Pelayanan." Hal tersebut didasarkan pada hasil uji T menunjukkan bahwa thitung > t tabel yaitu dengan angka 7,820 >0,098 dengan tingkat signifikansi $0,000<0,05$. Adapun besarnya pengaruh variabel Implementasi Electronic Government terhadap variabel Kualitas Pelayanan sebesar 0,339 atau $33,9 \%$ sisanya ditentukan oleh $66,1 \%$ dari pengaruh variabel lain.

Begitu pula yang terjadi pada Implementasi Electronic Government (X2), nilai perolehan persamaan model regresi linier berganda diketahui bahwa Implementasi Electronic Government (X2) menunjukkan nilai koefisien regresi positif, hal tersebut menunjukkan adanya arah positif atau hubungan searah dari Implementasi Electronic Government (X2) dengan Kualitas Pelayanan (Y). Oleh karenanya dapat diartikan bahwa jika semakin meningkat Implementasi Electronic Government maka Kualitas Pelayanan akan semakin meningkat, begitu pula sebaliknya jika semakin menurun Implementasi Electronic Government maka Kualitas Pelayanan akan semakin menurun.

\section{Pengaruh Kepemimpinan Birokrasi dan Implementasi Electronic} Government Secara Bersama-sama Terhadap Kualitas Pelayanan Publik

Hasil uji $F$ menunjukkan bahwa hipotesis Ha3 diterima yang berbunyi "Ada Pengaruh Kepemimpinan Birokrasi dan Penerapan Electronic Government secara bersama-sama terhadap Kualitas Pelayanan Kependudukan dan Pencatatan Sipil di Dinas Kependudukan dan Pencatatan Sipil Kota Cilegon." Terbukti dengan hasil $\mathrm{F}$ hitung $>\mathrm{F}$ tabel yaitu $76,286>3.02$ dengan tingkat signifikansi $0,000<0,05$. Adapun besar pengaruh Kepemimpinan Birokrasi dan
Pelaksanaan Electronic Government secara Bersama-sama terhadap Kualitas Pelayanan adalah $28,6 \%$.

Analisis Korelasi Ganda digunakan untuk mengetahui hubungan antara dua atau lebih variabel independen (X1, $\mathrm{X} 2, \ldots \mathrm{Xn}$ ) terhadap variabel dependen (Y) secara serentak. Koefisien ini menunjukkan seberapa besar hubungan yang terjadi antara variabel independen $(\mathrm{X} 1, \mathrm{X} 2, \ldots \mathrm{Xn})$ secara serentak terhadap variabel dependen (Y). Nilai $R$ berkisar antara 0 sampai 1, nilai semakin mendekati 1 berarti hubungan yang terjadi semakin kuat, sebaliknya nilai semakin mendekati 0 maka hubungan yang terjadi semakin lemah.

Menurut Sugiyono (2001), pedoman untuk memberikan interpretasi koefisien korelasi sebagai berikut:

$$
\begin{aligned}
& 0,00-0,199=\text { sangat rendah } \\
& 0,20-0,399=\text { rendah } \\
& 0,40-0,599=\text { sedang } \\
& 0,60-0,799=\text { kuat } \\
& 0,80-1,000=\text { sangat kuat }
\end{aligned}
$$

Model regresi linier ganda dalam penelitian ini, berdasarkan Tabel 4-13 memiliki nilai koefisien korelasi sebesar 0.535. Hal ini menunjukkan bahwa terjadi pengaruh yang sedang antara Kepemimpinan Birokasi dan Implementasi Electronic Government terhadap Kualitas pelayanan, karena nilai korelasi 0,535 terletak antara 0,40 sampai 0,599 .

Model regresi linier ganda tersebut memiliki nilai koefisien determinasi sebesar 0.286 atau $(28,6 \%)$. Hal ini menunjukkan bahwa pengaruh variabel independent (Kepemimpinan Birokrasi dan Implementasi Electronic Govenment) terhadap variabel dependen (Kualitas Pelayanan) sebesar 28,6\%. Sedangkan sisanya sebesar $71,4 \%$ dipengaruhi atau 
Jurnal Administrasi Negara

ISSN : 2598-4039 (Online)

ISSN : 2302-2231 (Print)
Mas Wigrantoro Roes Setyadi, dkk

Institut Pemerintahan Dalam Negeri, Jatinangor Jawa Barat dijelaskan oleh variabel lain yang tidak dimasukkan dalam model penelitian ini.

\section{PENUTUP \\ SIMPULAN}

Berdasarkan temuan hasil penelitian sebagai bentuk jawaban atas tiga rumusan masalah di atas, dibuat simpulan sebagai berikut:

1. Kepemimpinan Birokrasi terbukti berpengaruh positif terhadap Kualitas Pelayanan Publik, besarnya pengaruh adalah 0.396 atau $39.6 \%$. Hal ini menunjukkan semakin meningkat Kepemimpinan Birokrasi maka Kualitas Pelayanan Publik akan semakin meningkat, begitu pula sebaliknya jika semakin menurun Kepemimpinan Birokrasi maka Kualitas Pelayanan Publik akan semakin menurun. Dalam konteks Kepemimpinan Birokrasi dan pengaruhnya terhadap kinerja organisasi pemerintah dan Kualitas Pelayanan Publik, simpulan ini sejalan dengan Abah dan Nwoba (2006), UhlBien et al (2007), Zubaidi (2004), Amalia (2014), Hayat (2014), Hadian (2015), Idrus et al (2015), dan Qaisi (2015).

2. Implementasi Electronic Government terbukti berpengaruh positf terhadap Kualitas Pelayanan Publik, besarnya pengaruh adalah 0.339 atau $33.9 \%$. Hal ini menunjukkan semakin meningkat Implementasi Electronic Government maka Kualitas Pelayanan Publik akan semakin meningkat, begitu pula sebaliknya jika semakin menurun Implementasi Electronic Government maka Kualitas Pelayanan Publik akan semakin menurun.

Hasil ini mendukung pembuktian yang telah dilakukan sebelumnya oleh kelompok peneliti optimis (Baum \&
Di Maio, 2000; Hiller \&Belanger, 2001; Layne \& Lee, 2000; Ronaghan, 2002: Wescott, 2001) bahwa implementasi Electronic Government akan memberikan hasil positif, berevolusi secara alamiah melalui beberapa tahapan, bergerak dari penyediaan informasi dan layanan dasar kepada transaksi, interaksi, "penggabungan pemerintahan" (integrasi vertikal dan horisontal penyediaan informasi dan layanan di dalam suatu instansi dan antar-instansi pemerintah, ke transformasi pemerintahan hingga e-democracy).

Secara spesifik, dalam kaitan dengan peningkatan kualitas pelayanan publik, hasil penelitian ini juga mendukung pendapat bahwa implementasi Electronic Government menggeser paradigma menuju pemerintahan yang berorientasi warga (Ho, 2002), menggerakkan partisipasi warga dan meningkatkan akses masyarakat (Seifert dan Peterson, 2002), meningkatkan intensitas dan kualitas hubungan warga dengan pemerintah (Thomas dan Streib, 2003; Sharma, 2014), meningkatkan interaksi antar-warga dan antara warga dengan pemerintah (Reddick, 2005; Lee, Tan, dan Trimi, 2005); penyediaan format baru partisipasi warga dan meningkatkan proses demokrasi (Forcella, 2006); meningkatnya transparansi pemerintahan (Bolivar, Perez, dan Hernandes, 2007); dan meningkatkan akses, transparansi, efisiensi, dan kualitas (Bekkers dan Homburg, 2007); sintesis praktik Birokrasi dalam mewujudkan New Public Management (Persson \& Goldkuhl, 2010); meningkatkan posisi ekonomi dan 
Jurnal Administrasi Negara

ISSN : 2598-4039 (Online)

ISSN : 2302-2231 (Print)
Mas Wigrantoro Roes Setyadi, dkk

Institut Pemerintahan Dalam Negeri, Jatinangor Jawa Barat reputasi suatu negara (Aldabbas, 2013).

3. Kepemimpinan Birokrasi dan Implementasi Electronic Government secara bersama berpengaruh positif Kualitas Pelayanan Publik Kependudukan dan Pencatatan Sipil di Dinas Kependudukan dan Pencatatan Sipil Kota Cilegon, besarnya pengaruh adalah $28,6 \%$. Hal ini menunjukkan Implementasi Electronic Government yang didukung oleh Kepemimpinan Birokasi diperlukan untuk meningkatkan Kualitas Pelayanan Publik. Hasil penelitian ini juga menjelaskan bukti empiris yang terjadi di banyak Pemerintah Daerah di Indonesia, ketika Kepemimpinan Birokrasi menurun karena berbagai alasan (seperti terjadi pergantian pimpinan, anggaran yang dibutuhknn tidak mendapat dukungan dari pemimpin, pemimpin baru tidak memahami TIK, dan lain sebagainya) maka Kualitas Pelayanan Publik cenderung menurun meski sudah mengImplementasikan Electronic Government. Dalam kata lain dapat diungkapkan, implementasi Electronic Government mengalami stagnasi sehingga kualitas Pelayanan Publik Menurun karena menurunnya Kepemimpinan Birokasi.

Dari perspektif akademis terbuktinya hipotesis ketiga ini mendukung penelitian Fitriani et al (2016), bahwa Impelementasi Electronic Government mendukung proses pemerintahan dalam penyampaian layanan kepada masyarakat, dan kepemimpinan birokrasi yang tercermin dalam 12 faktor penentu kesuksesan Implementasi Electronic Government sangat diperlukan.

\section{SARAN}

Kepemimpinan Birokrasi dan Implementasi Electronic Government baik secara parsial maupun bersama berpengaruh positif terhadap Kualitas Pelayanan Kependudukan dan Pencatatan Sipil di Kota Cilegon. Guna menjaga kelestarian pengaruh positif ini, pimpinan Birokrasi Kota Cilegon disarankan untuk terus meningkatkan: Motivasi Pegawai, Kualitas Pegawai, Efektifitas Sosialisasi Pelayanan berbasis electronic Government, Budaya Organisasi berbasis Electronic Government, dan eLeadership.

Beberapa faktor dalam variabel Kepemimpinan Birokrasi yang memerlukan peningkatan kuantitas dan kualitas antara lain: memotivasi bawahan, sering memberi arahan, ikut turun tangan dalam melayani masyarakat. Faktor dalam variabel Implementasi Electronic Government yang memerlukan peningkatan kuantitas dan kualitas antara lain: membuat layanan berbasis online secara menyeluruh, melakukan sosialisasi kepada warga atau penduduk Kota Cilegon agar semakin banyak yang mengetahui keberadaan layanan berbasis online, Sedangkan faktor dalam variabel Kualitas Pelayanan yang perlu diperbaiki yakni: Kualitas Organisasi, membangun sistem yang membuka seluas-luasnya menerima masukan dari warga/ masyarakat.

Implementasi Electronic Government sebaiknya dimaksudkan sebagai reformasi birokrasi pemerintahan secara sistematis, mengubah dari pola kenaikan bertahap (incremental) menjadi reformasi secara sistematis yang berdampak jangka panjang terhadap pemerintahan (Ho, 2002; Tores, Pina dan Royo, 2005), mentransformasi relasi tradisional antara pemerintah dan warga sehingga 
Jurnal Administrasi Negara

ISSN : 2598-4039 (Online)

ISSN : 2302-2231 (Print)
Mas Wigrantoro Roes Setyadi, dkk

Institut Pemerintahan Dalam Negeri, Jatinangor Jawa Barat pemerintah menjadi lebih responsif dan akuntabel terhadap harapan warga.

Implementasi Electronic Government yang dimaksudkan untuk meningkatkan Kualitas Pelayanan Publik seringkali menghadapi resistensi dari pegawai pemerintah karena karyawan merasa kehilangan otoritas dan kontrol sebagaimana berlaku dalam proses bisnis konvensional (El-Haddadeh, 2010). Untuk itu Pemimpin Birokrasi memahami e-Strategi Birokrasi Pelayanan Publik.

Dari perspektif akademik, model eLeadership Birokrasi Pelayanan Publik dapat digunakan sebagai peluang untuk dikaji lebih lanjut, khususnya penajaman dengan dukungan teori-teori yang mutakhir. Dari aspek praktis dapat digunakan oleh Birokrasi Pemerintah dalam menjalankan kegiatan pelayanan publik. kajian akademik lanjutan diusulkan Guna memberikan pedoman pelaksanan strategi.

\section{REFERENSI}

Abah, E. O., Nwoba, M. O. E. (2016). Effects of Leadership and Political Corruption on Achieving Sustainable Development: Evidence from Nigeria, Public Policy and Administration Research www.iiste.org ISSN 22245731(Paper) ISSN 2225-0972(Online) Vol.6, No.6, 2016.

Amalia, N. (2014). Pengaruh Kepemimpinan, Motivasi, Serta Lingkungan Kerja Terhadap Kinerja Pegawai Dinas Pendapatan, Pengelolaan Keuangan dan Aset Kabupaten Barito Timur, Jurnal Administrasi Publik Dan Birokrasi, Vol 1, No 3 (2014).

Baum, C. H. \& Di Maio, A. (2000). Gartner's Four Phases of Electronic Government Model. http://www.gartner.com/id=317292 [accessed October 28, 2016].

Badan Pusat Statistik, Kota Cilegon Dalam Angka, 2017

Bekkers, V. \& Homburg, V. (2007). The Myths of Electronic Government: Looking beyond the Assumptions of a New and Better Government. AvolioInformation Society 23(5): 373-82.

Bolivar, M. et al. (2007). Electronic Government and E-Financial Reporting: The Case of Spanish Regional Governments. American Review of Public Administration 37(2): 142-77.

Budd, L. \& Harris, L. Eds. (2009). eGovernance: Managing or Governing?, Routledge.

Creswell, J. W. (1994). Research Design Qualitative \& Quantitative Approaches. California: Sage Publications.

El-Haddadeh, R., Weerakkody, C., Al-Shafi, S. H., Ali. M. (2010). E-Government Implementation Challenges: A Case Study. America Conference of Information System (AMCIS). 
Jurnal Administrasi Negara

ISSN : 2598-4039 (Online)

ISSN : 2302-2231 (Print)
Mas Wigrantoro Roes Setyadi, dkk

Institut Pemerintahan Dalam Negeri, Jatinangor Jawa Barat
Fitriani, et al. (2016). Critical Success Factors Of Electronic Government Implementation: A Case Study On Financial Audit Agency, Jurnal IIOABJ Vol. 7, Supl 1 tahun 2016.

Forcella, M. (2006). E-Democracy: Strategies and New Horizons for the European Union Policies. Journal of Electronic Government 3(2): 99-107.

Hadian, D. (2015). Pengaruh Kepemimpinan, Struktur Organisasi dan Budaya Organisasi terhadap Kinerja Dinas serta Implikasinya pada Pelayanan Publik, Jurnal Kontingensi Volume 3, No. 1, Juni 2015.

Hayat, (2014). Konsep Kepemimpinan Dalam Reformasi Birokrasi: Aktualisasi Pemimpin Dalam Pelayanan Publik Menuju Good Governance, Jurnal Borneo Administrator Vol. 10 No. 1, April 2014.

Hiller, J. S., Bélanger, F. (2001). Privacy Strategies for Electronic Government. In Electronic Government 2001, edited by Mark A. Abramson and Grady E. Means, 163-79. Lanham, MD: Rowman \& Littlefield.

Ho, Alfred Tat-Kei. (2002). Reinventing Local Governments and the Electronic Government Initiative. Public Administration Review 62(4): 434-44.

Idrus, A. et al. (2015). The Role of Bureaucratic Leadership, Organizational Culture, and Organizational Commitment on Organizational Performance (Study on the Local Government Task Force/ SKPD's Financial Administration Officials in Jayapura City Government), European Journal of Business and Management Vol.7, No.19, 2015.

Layne, K. \& Lee, J. (2001). Developing Fully Functional Electronic Government: A Four Stage Model. Government Information Quarterly 18(2): 122-36.

Lee, S. M., Tan, X., and Trimi, S. (2005). Current Practices of Leading Electronic
Government Countries. Communications of the ACM 48(10): 99-104.

Mohammad, H., Almarabeh, T. \& Abu Ali, A. (2009). E-government in Jordan, European Journal of Scientific Research, ISSN 1450-216X, 35(2), pp 188-197.

Ndraha, T. (1999). Pengantar Teori Pengembangan Sumberdaya Manusia, Jakarta: Rineka Cipta.

Persson, A. \& Goldkuhl, G. (2010), Government Value ParadigmsBureaucracy, New Public Management, and E-Government, Communications of the Association for Information Systems: Vol. 27, Article 4., 2010.

Qaisi, A. (2015). The Impact of Bureaucracy Characteristics on Leadership, Researchgate, August 2015.

Reddick, C. G. (2005). Citizen interaction with Electronic Government: From the streets to servers?, Journal Government Information Quaterly 22 (2005).

Riggs, F. W. et al (2009). Theoretical And Conceptual Perspectives On Bureaucracy And Bureaucratic Politics dalam Bureaucracy And Administration.

Ronaghan, S. A. (2002). Benchmarking Electronic Government: A Global Perspective. New York: United Nations Division for Public Economics and Public Administration and American Society for Public Administration. http://unpan1.un.org/intra-

doc/groups/public/documents/un/unpan02 1547. pdf [accessed October 28, 2012].

Seifert, J. W., and Petersen, E. (2002). e Promise of All ings E? Expectations and Challenges of Emergent Electronic Government. Perspectives on Global Development and Technology 1(2): 19321.

Suradinata, E. (2013). Analisis Kepemimpinan-Strategi Pengambilan Keputusan, Alqaprint Jatinangor, Sumedang. 
Thomas, J. C. \& Streib, G. (2003). e New Face of Government: Citizen- Initiated Contacts in the Era of Electronic Government. Journal of Public Administration Research and Theory 13(1): 83-102.

Torres, L., Pina, V., and Royo. S. (2005). Electronic Government and the Transformation of Public Administrations in the EU Countries: Beyond NPM or Just a Second Wave of Reforms? Online Information Review 29(5): 531-53.

Uhl-Bien, M. et al. (2007). Complexity Leadership Theory: Shifting Leadership from The Industrial Age to The Knowledge Era, The Leadership Quarterly Vol.18 no. 4, Agustust 2007.

Undang-Undang Republik Indonesia Nomor 25 Tahun 2009 Tentang Pelayanan Publik.

Undang-Undang Nomor 23 Tahun 2014 tentang Pemerintahan Daerah.

Wescott, C. (2001). Electronic Government in the Asia-Pacific Region. Asian Journal of Political Science 9(2): 1-24.

Zubaidi, A. (2014). The Influence of Servant Leadership and Bureaucracy Apparatus Behavior to The Service Performance in Resettlement Area in DKI Jakarta, The International Journal of Social Sciences Vol.27 no. 1, September 2014. 